\title{
Experimental analysis of reinforced concrete beams strengthened in bending with carbon fiber reinforced polymer
}

\section{Análise experimental de vigas de concreto armado reforçadas à flexão com polímero reforçado com fibra de carbono}
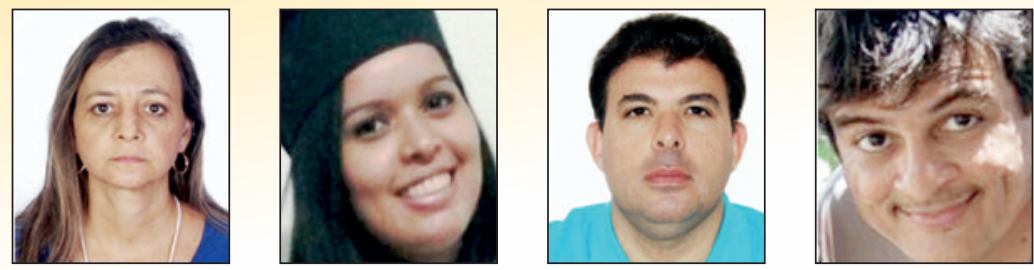

M. M. VIEIRA a

mylene.eng@gmail.com
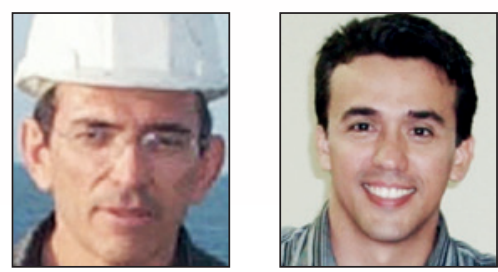

A. R. S. SANTOS : anarafaelasouzasantos@gmail.com

A. M. MONT'ALVERNE montalverne@ufc.br

L. M. BEZERRA leonardo.bezerra@ufc.br

L. C. S. MONTENEGRO c modulo@modulo.eng.br

A. E. B. CABRAL a, b eduardo.cabral@ufc.br

\section{Abstract}

The use of carbon fiber reinforced polymer (CFRP) has been widely used for the reinforcement of concrete structures due to its practicality and versatility in application, low weight, high tensile strength and corrosion resistance. Some construction companies use CFRP in flexural strengthening of reinforced concrete beams, but without anchor systems. Therefore, the aim of this study is analyze, through an experimental program, the structural behavior of reinforced concrete beams flexural strengthened by CFRP without anchor fibers, varying steel reinforcement and the amount of carbon fibers reinforcement layers. Thus, two groups of reinforced concrete beams were produced with the same geometric feature but with different steel reinforcement. Each group had five beams: one that is not reinforced with CFRP (reference) and other reinforced with two, three, four and five layers of carbon fibers. Beams were designed using a computational routine developed in MAPLE software and subsequently tested in 4-point points flexural test up to collapse. Experimental tests have confirmed the effectiveness of the reinforcement, ratifying that beams collapse at higher loads and lower deformation as the amount of fibers in the reinforcing layers increased. However, the increase in the number of layers did not provide a significant increase in the performance of strengthened beams, indicating that it was not possible to take full advantage of strengthening applied due to the occurrence of premature failure mode in the strengthened beams for pullout of the cover that could have been avoided through the use of a suitable anchoring system for CFRP.

Keywords: flexural strengthening, carbon fiber reinforced polymer, reinforced concrete beam.

\section{Resumo}

Os polímeros reforçados com fibra de carbono (PRFC) têm sido bastante utilizados no reforço de estruturas de concreto armado devido à sua praticidade e versatilidade na aplicação, baixo peso e elevada resistência à tração e à corrosão. Algumas empresas que atuam no mercado da construção civil utilizam o PRFC no reforço à flexão de vigas de concreto armado, contudo sem fazer uso de sistemas de ancoragem, o que influencia na capacidade resistente da viga. Portanto, o objetivo desse trabalho é analisar, por meio de um programa experimental, o comportamento estrutural de vigas de concreto armado reforçadas à flexão com PRFC variando-se a taxa de armadura e a quantidade de camadas do reforço, sem fazer o uso de sistemas de ancoragem. Para tanto, foram produzidos dois grupos de vigas de concreto armado, de mesma característica geométrica mas com taxas de armadura distintas. Cada grupo possuía cinco vigas: uma que não foi reforçada (de referência) e as demais reforçadas com duas, três, quatro e cinco camadas de fibra de carbono. As vigas foram dimensionadas utilizando-se uma rotina computacional desenvolvida no pacote comercial MAPLE, sendo posteriormente ensaiadas à flexão em 4 pontos até o seu colapso. Os ensaios experimentais comprovaram a eficácia do reforç, constatando-se que as vigas colapsavam com cargas superiores e deformaçoes inferiores à medida que se aumentava a quantidade de camadas de fibra no reforço. Contudo o aumento do número de camadas não proporcionou um incremento expressivo na capacidade resistente das vigas reforçadas, indicando que não foi possível tirar proveito por completo do reforço aplicado devido a ocorrência nas vigas reforçadas do modo de ruína prematuro por arrancamento do cobrimento que poderia ter sido evitado com o uso de um sistema de ancoragem adequado para o PRFC.

Palavras-chave: reforço à flexão, polímero reforçado com fibra de carbono, viga de concreto armado.

Programa de Pós-Graduação em Engenharia Civil: Estruturas e Construção Civil, Universidade Federal do Ceará, Fortaleza, CE, Brasil;

Grupo de Pesquisa em Materiais de Construção e Estruturas - GPMATE, Universidade Federal do Ceará, Fortaleza, CE, Brasil;

Módulo Engenharia Ltda, Fortaleza, CE, Brasil.

Received: 12 Dec2014 • Accepted: 09 Nov 2015 • Available Online: 27 Jan 2016 


\section{Introduction and justification}

A reinforced concrete structure must withstand various assaults and actions over time, and at the same time, must meet the requirements of its users. However, occasionally interventions in these structures may be required to restore or increase their original load capacity.

Among the various existing strengthening techniques of reinforced concrete structures, the carbon fiber reinforced polymers (CFRP) have advantages over other strengthening materials, such as their ease of application, the material lightness, high mechanical strength, corrosion resistance, electromagnetic neutrality, among other [1].

The CFRP has been internationally studied to enhance the flexural strength of reinforced concrete beams since the 1990s [2]. Currently, it's already being compared the performance of the carbon fibers with other fibers, such as glass [3], or being investigated the effectiveness of the transverse clamping with CFRP layers to prevent the premature debonding of the strengthening [4], as well as, being researched the use of the CFRP in the strengthening of the shear of beams [5].

In Brazil, there is already a history of research and application of CFRP in the flexural strengthening of reinforced concrete beams, such as: Beber's work [6-7] that show the main structural implications of CFRP bonded externally to the reinforced concrete beams strengthened in bending and shear; Ferrari [8], who evaluated the efficiency of the strengthening technique in reinforced concrete beams with CFRP, with the stressed chord previously reconstituted with a high-performance composite; and Costa [9], who evaluated the behavior of reinforced concrete beams strengthened with CFRP and optimization parameters of the strengthening using the reduction of anchor length. It is worth noting that in all these works the CFRP was anchored with bands on the transversal edges (transverse clamping).

According to the studies cited above, the use of the CFRP for the flexural strengthening of reinforced concrete beams has been effective both to increase the load capacity and the rigidity of the beams.

However, there are cases in Brazil in which the flexural strength- ening of reinforced concrete beams with CFRP still has been designed using commercial packages based on the requirements of the 2002 release of $\mathrm{ACl} 440.2 \mathrm{R}$ guide [10], which allows the design of the strengthening without the use of an anchor system for the CFRP. Thus, there are still several CFRP flexural strengthenings made commercially in beams without the use of anchor systems. It is important to highlight that the recommendation for the use of anchor systems aims to prevent a premature failure of the structural element and it can be found in various scientific papers [6-9; 11-14]. Comparing the requirements of the 2008 release of $\mathrm{ACI}$ $440.2 R$ guide [15] with the requirements of the 2002 release of the same guide [10], it can be observed that 2008 release imposed a greater constraint for the strain of the CFRP in order to avoid the occurrence of the premature failure mode.

Thus, the objective of this study is to evaluate the structural behavior of reinforced concrete beams flexural strengthened with CFRP once the reinforcement rate and the amount of layers of carbon fiber are varied, without the use of an anchor system for them, enabling to make an analysis of efficacy of the strengthening as a function of the load increase that is desired. The differential of this work from others already published on the subject is that this does not use an anchor system for the CFRP, being possible use its results to guide the design of the flexural strengthening of reinforced concrete beams that do not yet use an anchor system, considering the economy and safety.

\section{Materials and experimental program}

\subsection{Characteristics of the beams}

Ten reinforced concrete beams were made with rectangular cross section of $120 \mathrm{~mm}$ (width) by $245 \mathrm{~mm}$ (height) with total length of $2800 \mathrm{~mm}$ and span of $2400 \mathrm{~mm}$, which were divided into two groups (VA and VB), differentiated by the reinforcement rate. For the assay, the beams were simply supported and loaded with concentrated loads $(\mathrm{P} / 2)$ acting on two points as shown in Figure 1. Both VA and VB beams were designed to the collapse occurs due to the yielding of the bottom longitudinal reinforcement with no crushing of the concrete in compression. In both groups, the top

Figure 1 - Dimensions and loadings of the beams

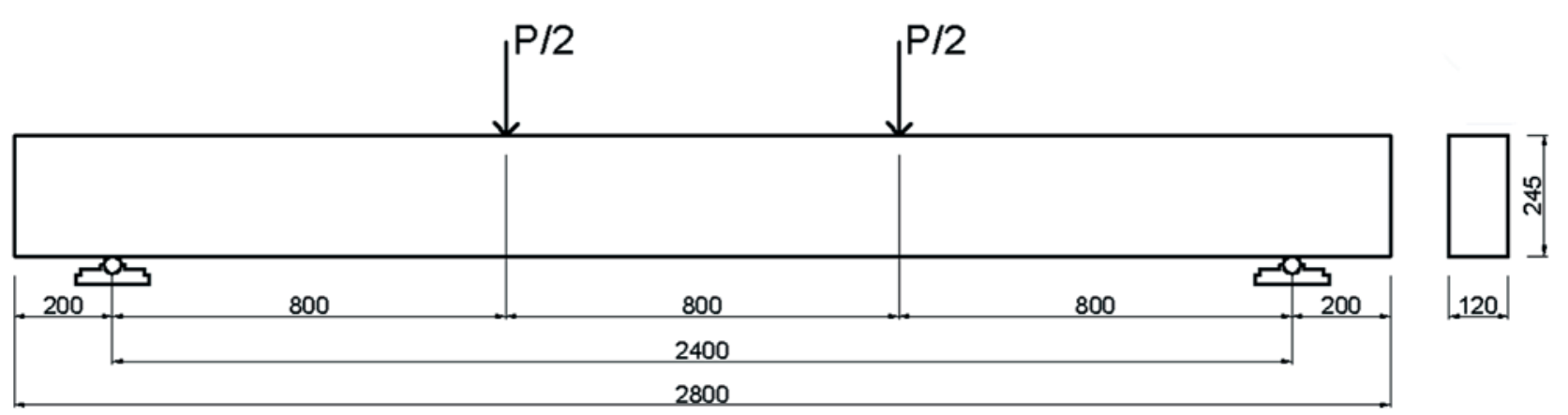

dimensions in $\mathrm{mm}$ 


\section{Figure 2 - Detailing of the reinforcements of the VA beams}

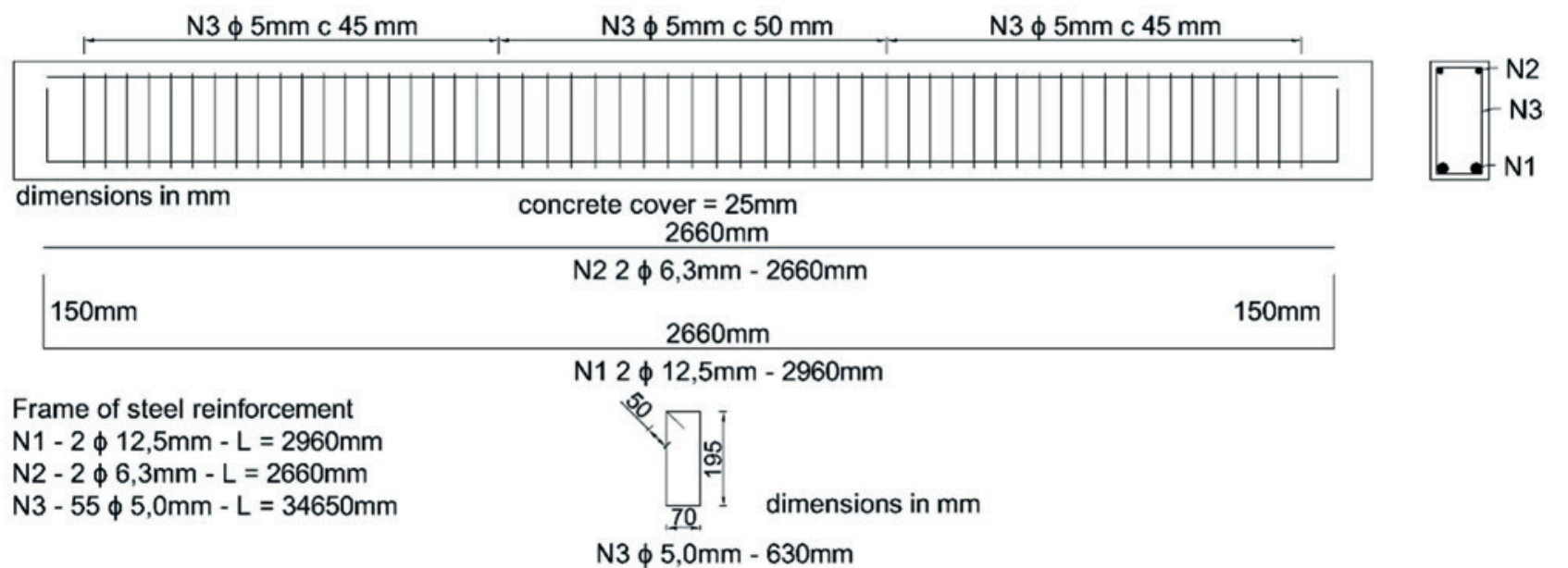

reinforcement consisted of two CA-50 steel bars with diameter of $6.3 \mathrm{~mm}$ and stirrups of CA-60 steel bars with diameter of $5.0 \mathrm{~mm}$. For the VA beams, the bottom reinforcement was composed of two CA-50 steel bars with $12.5 \mathrm{~mm}$ of diameter, while for the VB beams, this reinforcement was composed of two CA-50 steel bars with $10.0 \mathrm{~mm}$ of diameter. The Figure 2 provides the detailing of the reinforcements of the VA beams. The detailing of the VB beams is identical to the VA beams. The exception is the bottom longitudinal reinforcement (N1), which is $10 \mathrm{~mm}$ in diameter in VB beams. All beams were built on the same day with the use of ready-mix concrete and manual casting. The concrete vibration was made with a needle immersion vibrator with $25 \mathrm{~mm}$ diameter. The beams and the concrete specimens were kept in wet curing on the upper surface after the concreting until the stripping, which took place three days after the concreting. After the stripping, for a period of seven days, the beams were kept in wet curing covered with geotextile sail humidified twice daily. After the curing, the beams and the specimens were kept at laboratory environment until the date of the tests.

\subsection{Characteristics of the CFRP strengthenings}

The CFRP flexural strengthening in the beams has $2360 \mathrm{~mm}$ long and is centered between the supports and bonded on the bottom of the beams (Figure 3). For each group of beams were produced one reference beam (unstrengthened) and four strengthened beams with carbon fiber fabric (fibers with unidirectional orientation), which were positioned in the longitudinal direction of the beams, with the number of fiber layers ranging from two to five.

The specific characteristics of the concrete, steel and carbon fiber used in this work are presented in Table 1.

After fourteen days from the date of the casting, the beams were strengthened following manufacturer execution procedure, which consisted of the following steps: preparation of the surface using electric sander, application of one layer of primer bicomponent (in the ratio 2:1), application of one resin layer of bicomponent regularization (in the ratio 3.75:1), application of the first layer of the bicomponent saturating epoxy resin (in the ratio 2:1) and application of the carbon fiber layers interleaved with the saturating resin.

Figure 3 - Positioning of the strengthening in the beams

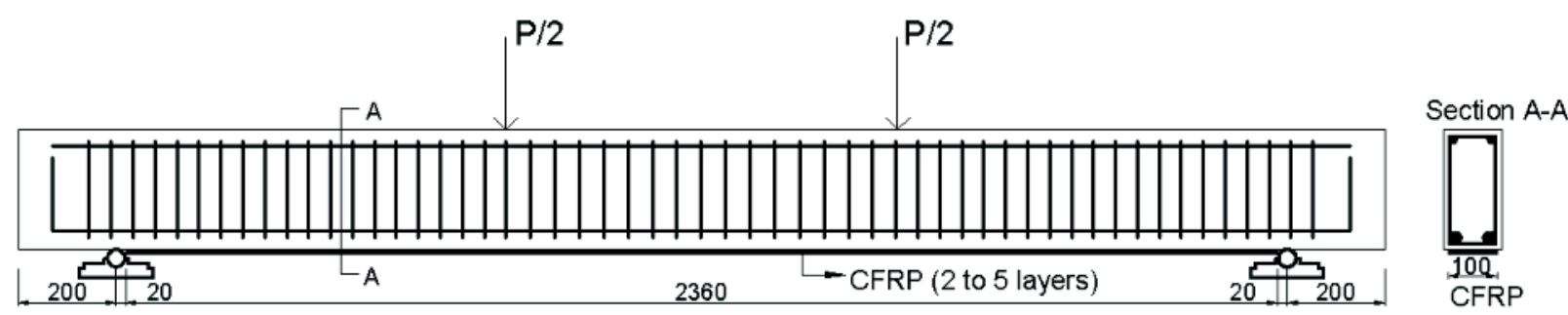

dimensions in $\mathrm{mm}$ 
Table 1 - Characteristics of the concrete, steel and carbon fiber used

\begin{tabular}{|c|c|c|c|}
\hline Material & Input & \multicolumn{2}{|c|}{ Type/Value } \\
\hline \multirow{9}{*}{ Concrete } & Cement & \multicolumn{2}{|c|}{ CP \| E 32} \\
\hline & Sand & \multicolumn{2}{|c|}{ Natural; FM=2.7 } \\
\hline & Gravel & \multicolumn{2}{|c|}{ Granitic; MDS=19 mm } \\
\hline & Additive & \multicolumn{2}{|c|}{ Plasticizer polyfunctional with retardant } \\
\hline & Water & \multicolumn{2}{|c|}{ From the public distribution network } \\
\hline & $f_{c k}$ & \multicolumn{2}{|c|}{$30.0 \mathrm{MPa}$} \\
\hline & $f_{c j} 28$ days & \multicolumn{2}{|c|}{$33.5 \mathrm{MPa}$} \\
\hline & $f_{c j} 135$ days & \multicolumn{2}{|c|}{$44.0 \mathrm{MPa}$} \\
\hline & $E_{c j} 135$ days & \multicolumn{2}{|c|}{$30.5 \mathrm{GPa}$} \\
\hline \multirow{6}{*}{ Steel } & $\mathrm{E}_{\mathrm{s}} 10 \mathrm{~mm}$ & \multicolumn{2}{|c|}{$189.6 \mathrm{GPa}$} \\
\hline & $\mathrm{E}_{\mathrm{s}} \varnothing 12,5 \mathrm{~mm}$ & \multicolumn{2}{|c|}{$217.0 \mathrm{GPa}$} \\
\hline & $\mathrm{f}_{\mathrm{st}} \varnothing 10 \mathrm{~mm}$ & \multicolumn{2}{|c|}{$655.0 \mathrm{MPa}$} \\
\hline & $\mathrm{f}_{\mathrm{st}} \varnothing 12,5 \mathrm{~mm}$ & \multicolumn{2}{|c|}{$656.3 \mathrm{MPa}$} \\
\hline & $\varepsilon_{y} \varnothing 10 \mathrm{~mm}$ & \multicolumn{2}{|c|}{$2.43 \%$} \\
\hline & $\varepsilon_{y} \varnothing 12,5 \mathrm{~mm}$ & \multicolumn{2}{|c|}{$2.55 \%$} \\
\hline \multirow{4}{*}{ Carbon fiber } & CFW300 & $\mathrm{E}_{\mathrm{fc}}$ & $230 \mathrm{GPa}$ \\
\hline & CFW300 & Fabric thickness & $0.166 \mathrm{~mm}$ \\
\hline & Epoxy resin & Ultimate strain & $2.1 \%$ \\
\hline & Epoxy resin & $f_{t}$ & $29 \mathrm{MPa}$ \\
\hline \multicolumn{4}{|c|}{ 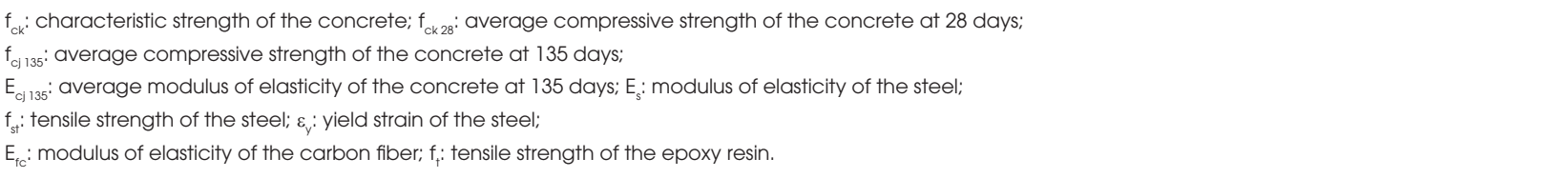 } \\
\hline
\end{tabular}

\subsection{Instrumentation and description of the test}

The structural behavior of the beams was monitored during the tests by the measurements of the strains on the bottom longitudinal reinforcement, on the shear reinforcement, on the concrete in the compression zone and on the strengthening with the use of electrical strain gauges, while vertical displacements were measured at the mid of the central span, in one of the points of loads' application and in the supports by displacement transducers. The load cells used had $500 \mathrm{KN}$ load capacity. The Figure 4 presents, illustratively, the positioning of the beams' instrumentation.

The load, strain and displacement data were obtained in real time and simultaneously by an HBM automatic acquisition system, Spider 8 model, using the Catman Easy software. The beams were tested using a frame fixed to a reaction slab positioned on both support devices. Loads were applied by means of combination

\section{Figure 4 - Positioning of the strain gauges and of the transducers}

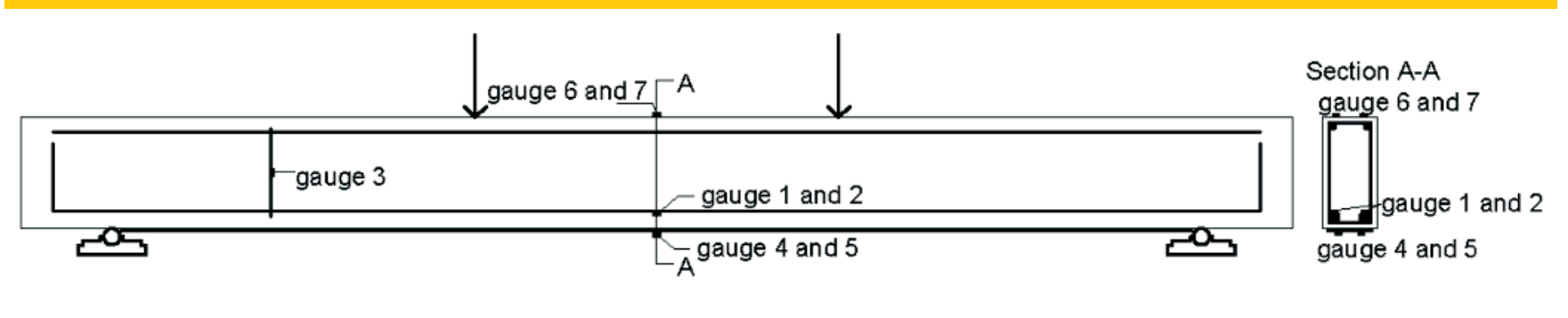


Figure 5 - Beams of the VA group in the collapse. a) VA-R; b) VA-2; c) VA-3; d) VA-4; e) VA-5

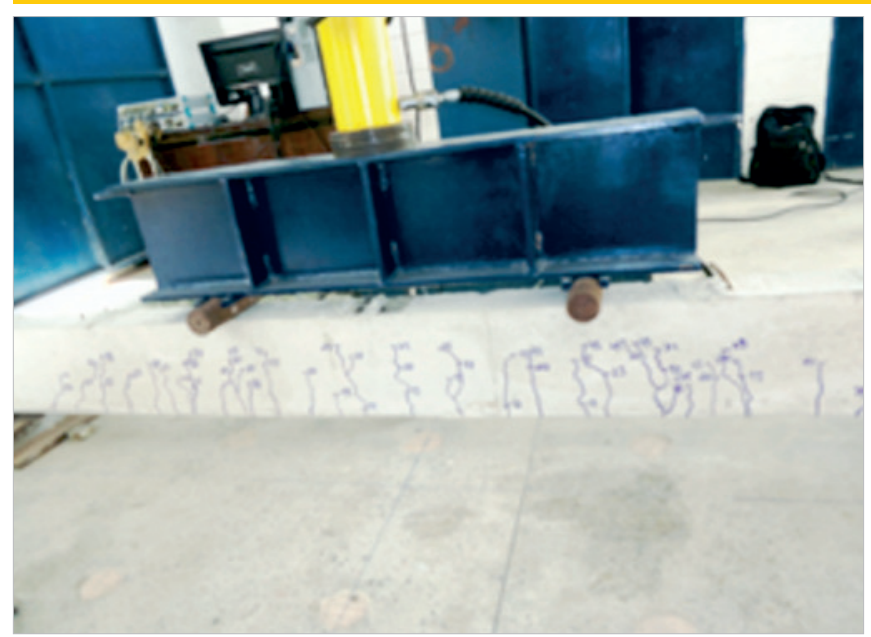

A VA-R beam in the collapse

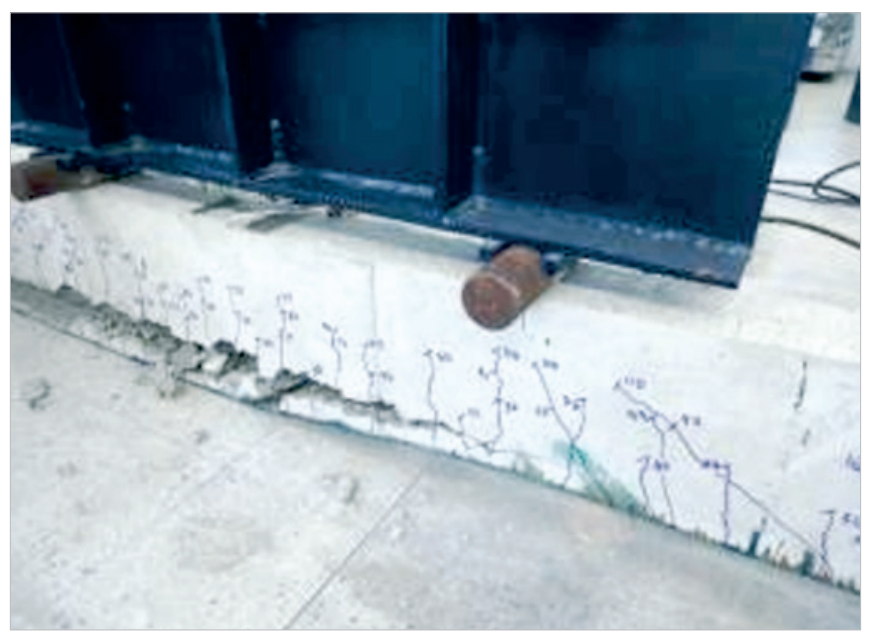

C VA-3 beam in the collapse

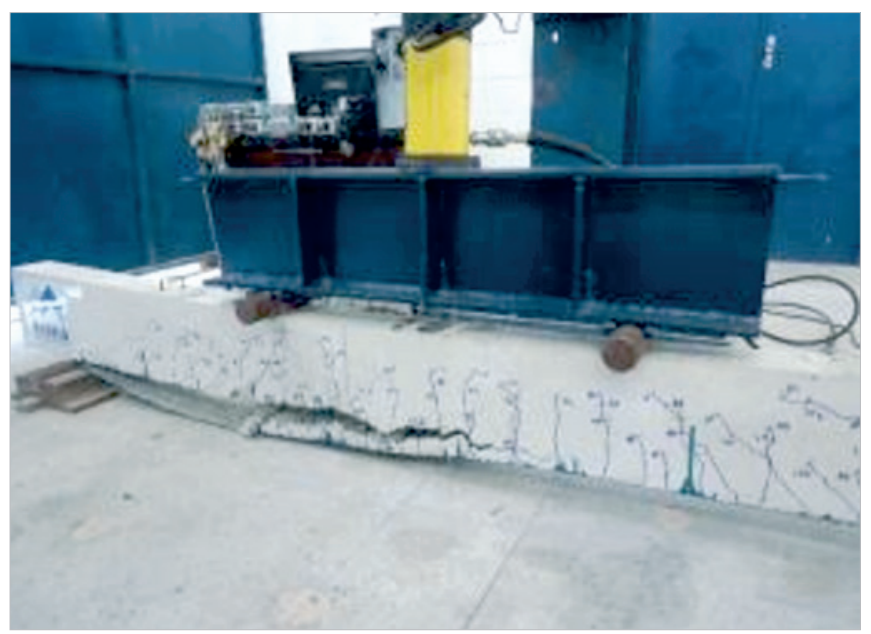

B VA-2 beam in the collapse

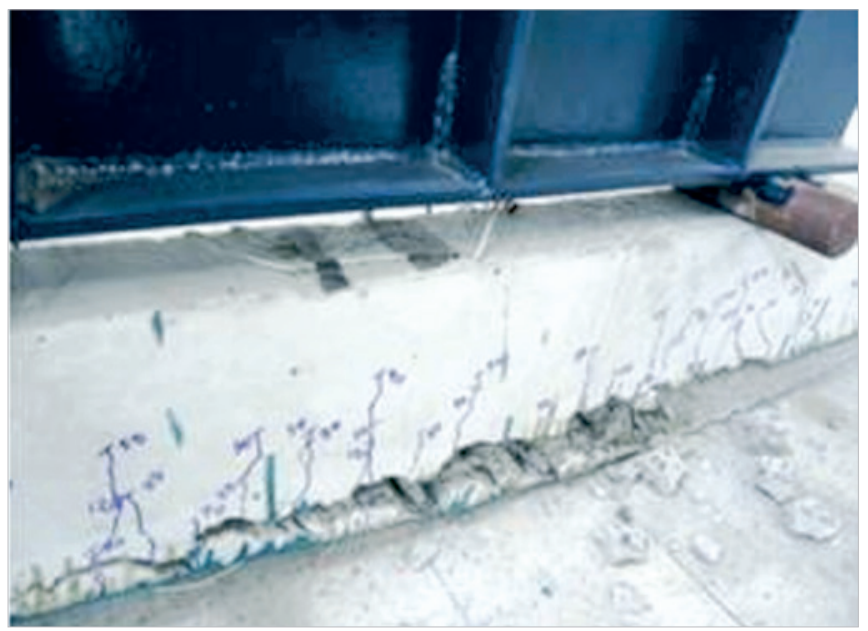

D VA-4 beam in the collapse

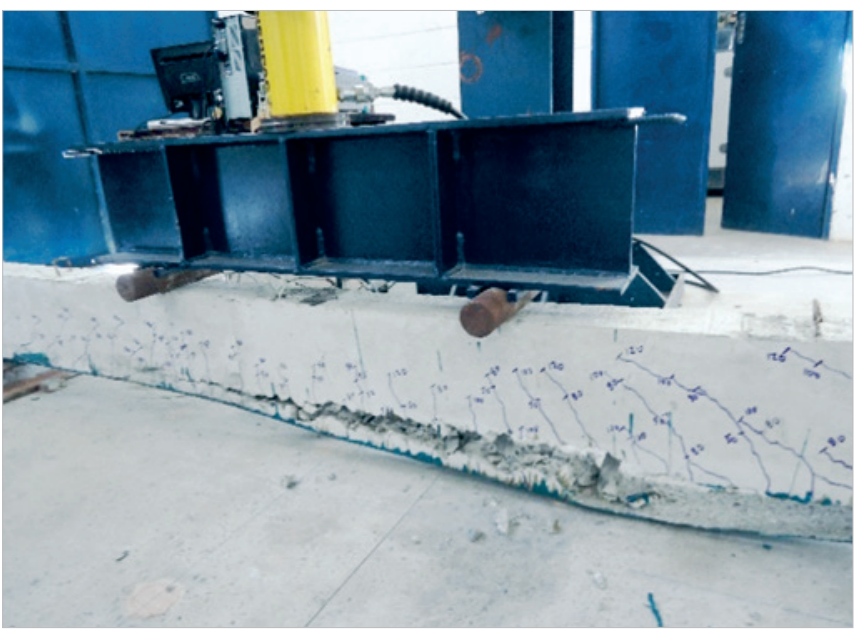

E VA-5 beam in the collapse 
Figure 6 - beams of the VB group in the collapse. a) VB-R; b) VB-2; C) VB-3; d) VB-4; e) VB-5

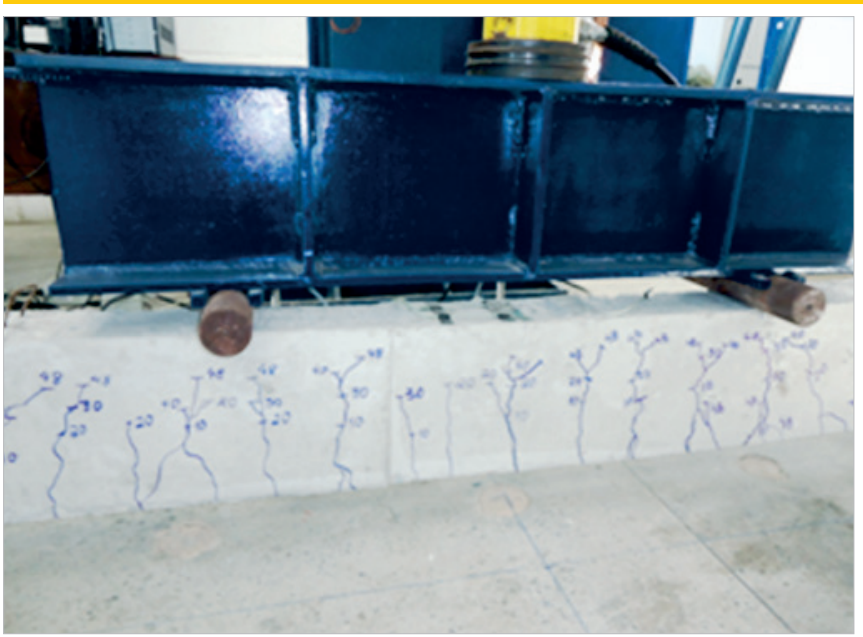

A VB-R beam in the collapse

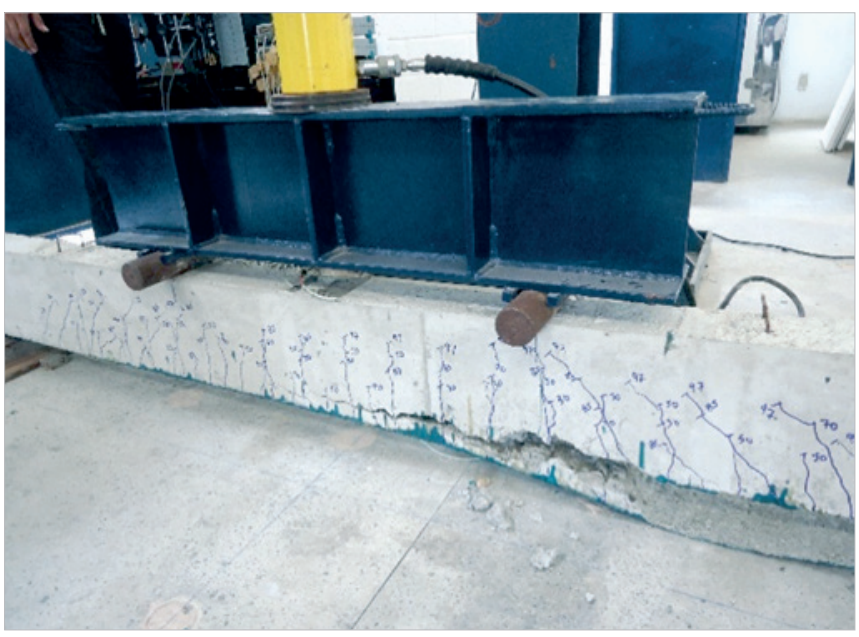

C VB-3 beam in the collapse

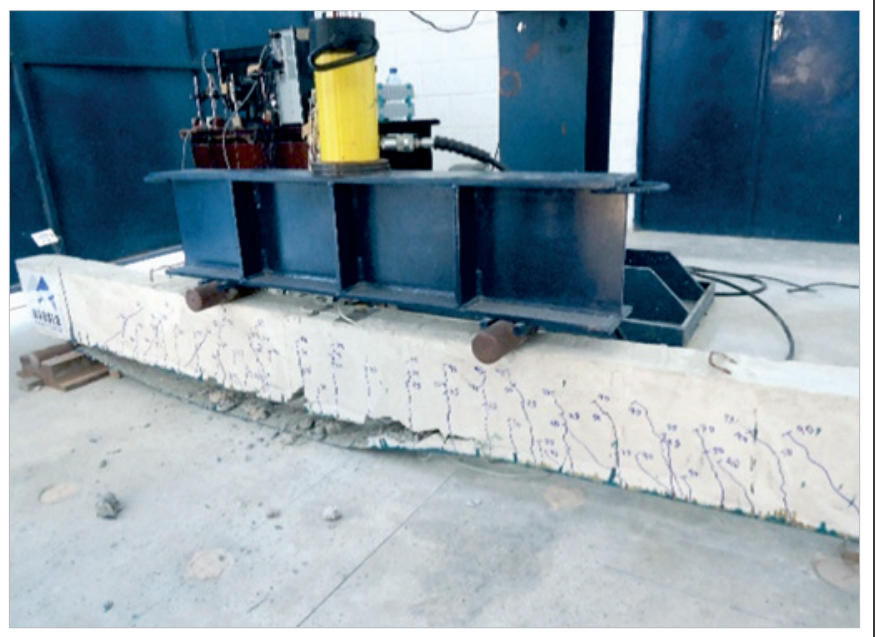

B VB-2 beam in the collapse

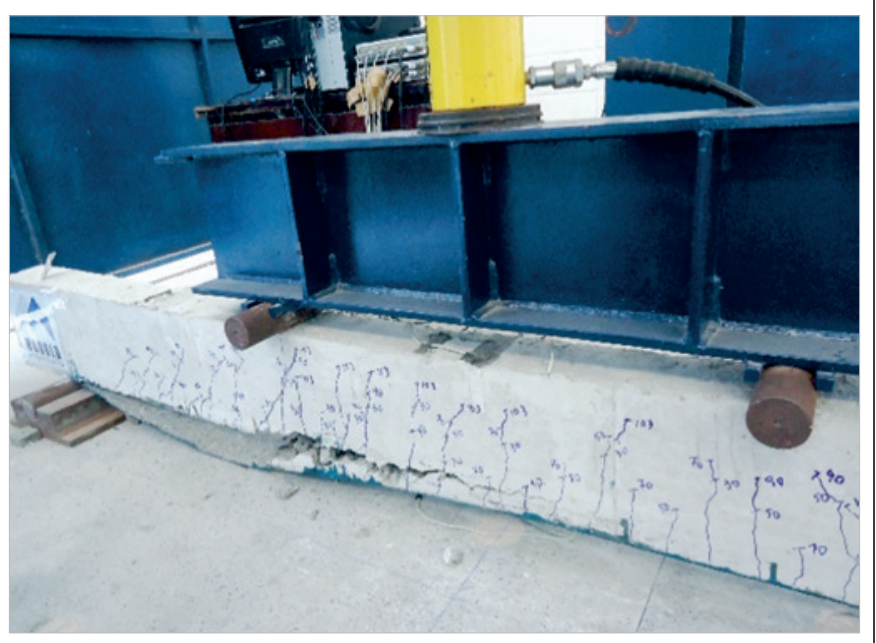

D VB-4 beam in the collapse

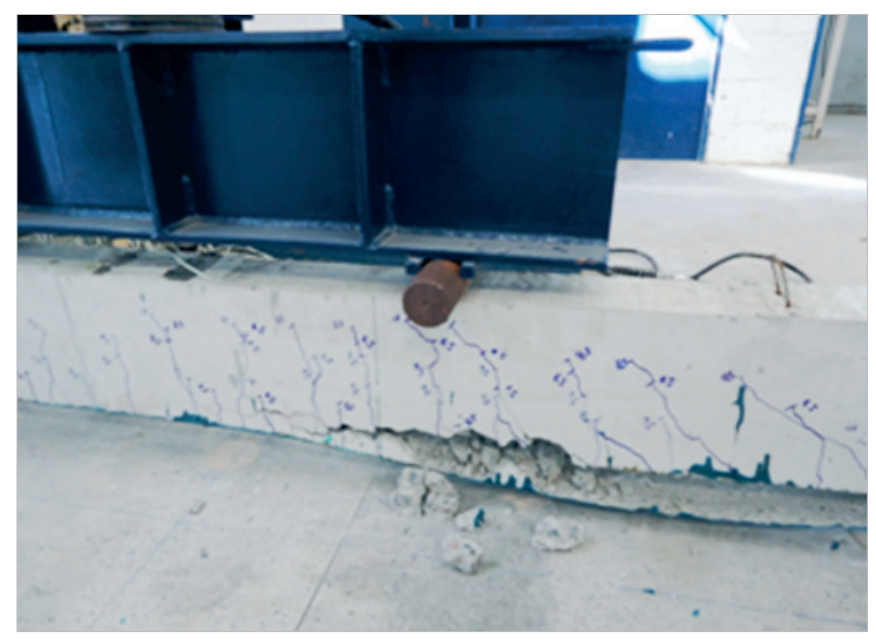

E VB-5 beam in the collapse 
composed by a hydraulic cylinder (load actuator) and a manual hydraulic jack.

The beams were subjected to simple flexural test. At the beginning of each test, the beams were subjected to a load for the accommodation of the structure, unloaded, and then loaded with increasing load until failure with intervals of load of $20 \mathrm{KN}$ approximately, monitoring the propagation of the cracks in the beams throughout the tests.

\section{Results and discussions}

\subsection{Experimental ultimate loads and failure modes}

Several authors classify the failure modes of strengthened beams with CFRP in classics, namely: crushing of the concrete [16-17], yielding of the steel could be followed by the crushing of the concrete [16-17], yielding of the steel could be followed by the rupture of the strengthening [16] and shear failure [8]; and premature such as: debonding of the strengthening by crack of bending [18] or flexure-shear, failure by debonding of the strengthening caused by critical diagonal crack [18-19], failure by rupture of the concrete cover [18], debonding of the strengthening [20], failure by debonding of the strengthening and by delamination of the concrete cover [18], interlaminar rupture of the strengthening [16] and debonding at the interface between the adhesive and the concrete or between the adhesive and the CFRP [16].

Figures 5-a to 5-e present the reference beams (VA-R) and of the strengthened beams with two (VA-2), three (VA-3), four (VA4 ) and five (VA-5) fiber layers, respectively, in the collapse, while Figures 6-a to 6-e are presented the collapse of the beams of the VB group, in this same order.

Table 2 shows the values of the ultimate experimental loads $\left(\mathrm{P}_{\mathrm{e}}\right)$ and the failure modes observed in the tested beams.
According to Table 2, as for VA group as for VB group, it is observed that there is an increment in the ultimate experimental load once the amount of fiber layers of the strengthening is increased. In the strengthened beams of the VA group, there was a considerable increase of the load capacity with additions between $55.1 \%$ and $86.8 \%$, for two and five strengthening layers, respectively, relative to the reference beam VA-R, while strengthened beams of the VB group increases load even more significantly, ranging from $89.5 \%$ to $126.2 \%$ for two and five strengthening layers, respectively, relative to the reference beam VB-R.

The highest increase in VB group is because all beams have lower reinforcement rate when compared with the beams of VA group. Thus, it is observed that the use of the strengthening for increasing the load capacity of the beams is limited by the reinforcement rate of them. It can further be seen that for the two groups of tested beams, the largest increase in load capacity of the beams considering the number of layers used was obtained with beams strengthened with two layers of fiber.

According to Table 2 data, when going from two to three, three to four and four to five layers of fiber, there were increases of $7.6 \%, 7.1 \%$ and $4.5 \%$ respectively, to VA group and $4.7 \%, 6.8 \%$ and $6.8 \%$, respectively, to VB group. This indicates that for strengthenings with more than two layers of fiber, increasing the number of layers does not provide a significant increase in load capacity, since all the strengthened beams showed premature failure by delamination of concrete cover (failure mode 2), indicating that was not possible to take advantage completely of the applied strengthening. One solution to prevent this premature failure mode would be to use an anchor system suitable for CFRP, which has not been used intentionally in this experiment.

As can be seen in Figures 5-a, and 6-a, reference beams VA-R

\section{Table 2 - Ultimate experimental loads and failure modes of the beams}

\begin{tabular}{|c|c|c|c|c|c|c|c|}
\hline Group & Beam & $A_{f}\left(\mathrm{~cm}^{2}\right)$ & $A_{s}\left(\mathrm{~cm}^{2}\right)$ & $P_{e}(k N)$ & $\begin{array}{l}\text { Difference from reference } \\
\text { beam, in percentage }(\%)\end{array}$ & $\begin{array}{c}\text { Difference from the beam } \\
\text { with one less fiber layer, in } \\
\text { percentage }(\%)\end{array}$ & $\begin{array}{l}\text { Failure } \\
\text { mode }\end{array}$ \\
\hline \multirow{5}{*}{ VA } & VA-R & 0.00 & \multirow{5}{*}{2.45} & 72.6 & - & - & 1 \\
\hline & VA-2 & 0.332 & & 112.7 & 55.1 & - & 2 \\
\hline & VA-3 & 0.498 & & 121.3 & 66.9 & 7.6 & 2 \\
\hline & VA-4 & 0.664 & & 129.9 & 78.8 & 7.1 & 2 \\
\hline & VA-5 & 0.830 & & 135.7 & 86.8 & 4.5 & 2 \\
\hline \multirow{5}{*}{ VB } & VB-R & 0.00 & \multirow{5}{*}{1.57} & 49.1 & - & - & 1 \\
\hline & VB-2 & 0.332 & & 93.1 & 89.5 & - & 2 \\
\hline & VB-3 & 0.498 & & 97.4 & 98.3 & 4.7 & 2 \\
\hline & VB-4 & 0.664 & & 104.0 & 111.7 & 6.8 & 2 \\
\hline & VB-5 & 0.830 & & 111.1 & 126.2 & 6.8 & 2 \\
\hline \multicolumn{8}{|c|}{$\begin{array}{l}P_{e} \text { - ultimate experimental load } \\
A_{f} \text { - carbon fiber area } \\
A_{s} \text { - area of the bottom longitudi } \\
1 \text { - failure by bending } \\
2 \text { - failure by cover delamination }\end{array}$} \\
\hline
\end{tabular}


Table 3 - Analytical and experimental values of the ultimate loads

\begin{tabular}{|c|c|c|c|c|c|c|}
\hline \multirow[b]{2}{*}{ Group } & \multirow[b]{2}{*}{ Beam } & \multirow[b]{2}{*}{$\begin{array}{c}A_{s} \\
\left(\mathrm{~cm}^{2}\right)\end{array}$} & \multirow[b]{2}{*}{$\begin{array}{c}A_{f} \\
\left(\mathrm{~cm}^{2}\right)\end{array}$} & \multicolumn{2}{|c|}{ Ultimate loads (kN) } & \multirow{2}{*}{$\begin{array}{c}\text { Percentage } \\
\text { difference } \\
\text { between } \\
P_{e} \in P_{a}\end{array}$} \\
\hline & & & & $\begin{array}{c}\text { Analytical } \\
P_{a}\end{array}$ & $\begin{array}{c}\text { Experimental } \\
P_{e}\end{array}$ & \\
\hline \multirow{5}{*}{$A$} & VA-R & \multirow{5}{*}{2.45} & 0.00 & 65.0 & 72.6 & 11.8 \\
\hline & VA-2 & & 0.332 & 111.6 & 112.7 & 1.0 \\
\hline & VA-3 & & 0.498 & 127.9 & 121.3 & -5.2 \\
\hline & VA-4 & & 0.664 & 135.3 & 129.9 & -4.0 \\
\hline & VA-5 & & 0.830 & 146.2 & 135.6 & -7.2 \\
\hline \multirow{5}{*}{ B } & VB-R & \multirow{5}{*}{1.57} & 0.00 & 41.9 & 49.1 & 17.0 \\
\hline & VB-2 & & 0.332 & 92.2 & 93.0 & 1.0 \\
\hline & VB-3 & & 0.498 & 116.8 & 97.4 & -16.6 \\
\hline & VB-4 & & 0.664 & 124.8 & 103.9 & -16.7 \\
\hline & VB-5 & & 0.830 & 134.8 & 111.1 & -17.6 \\
\hline $\begin{array}{l}A_{s} \text { - area of long } \\
A_{t}-\text { area of carb }\end{array}$ & reinforce & & & & & \\
\hline
\end{tabular}

and VB-R, respectively, showed failure by bending with excessive strain in the longitudinal bottom reinforcement, observed by bending cracks in the middle of the span, followed by large strains in the concrete, occurring only in the final loading stages, despite crushing concrete in the upper flange of the beam has not been observed.

With respect to the strengthened beams, the beginning of the failures occurred with a crack at the edge of the strengthening spreading in the horizontal direction, triggering a process of rupture of the concrete layer near to the bottom longitudinal reinforcement (concrete cover) along the length between one of the supports and one of the load application points, as can be seen in Figures 5-b to 5-e and Figures 6-b to 6-e. This failure mode is well known in specialized literature and is associated with the mechanism of strain transfer between concrete and strengthening, with rupture associated with the combination of shear and tensile stresses in this region starting from the edge of the strengthening [21].

\subsection{Comparison between the analytical and experimental ultimate load results}

Table 3 shows the comparisons between experimental ultimate loads $(\mathrm{Pe})$ and the design analytical ultimate loads $(\mathrm{Pa})$ obtained by computational analysis [22] developed in the commercial package MAPLE [23], based on 2002 release ACI 440.2R guide recommendations [10].

To prevent detachment of CFRP, the implemented computational routine introduces a restriction on the strain developed through the strengthening of the coefficient $k_{m}$ shown in Equation (1).

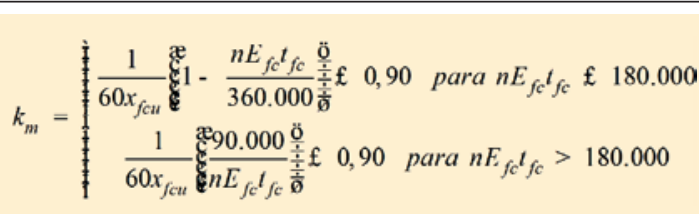

\section{Table 4 - Vertical displacements of VA beams}

\begin{tabular}{|c|c|c|c|c|c|}
\hline Group & Beam & $\mathbf{N}^{\circ}$ of fiber layers & $\begin{array}{l}\text { Displacement } \\
\text { for } 72,6 \mathrm{kN} \\
(\mathrm{mm})\end{array}$ & $\begin{array}{l}\text { Displacement } \\
\text { for } 110 \mathrm{kN} \\
(\mathrm{mm})\end{array}$ & $\begin{array}{l}\text { Displacement for } \\
\text { the ultimate load } \\
\text { (mm) }\end{array}$ \\
\hline \multirow{5}{*}{ VA } & VA-R & No reinforcement & 36.55 & - & 36.55 \\
\hline & VA-2 & 2 & 15.90 & 32.30 & 35.15 \\
\hline & VA-3 & 3 & 16.17 & 30.34 & 35.69 \\
\hline & VA-4 & 4 & 14.90 & 23.88 & 35.01 \\
\hline & VA-5 & 5 & 13.47 & 22.21 & 32.40 \\
\hline
\end{tabular}




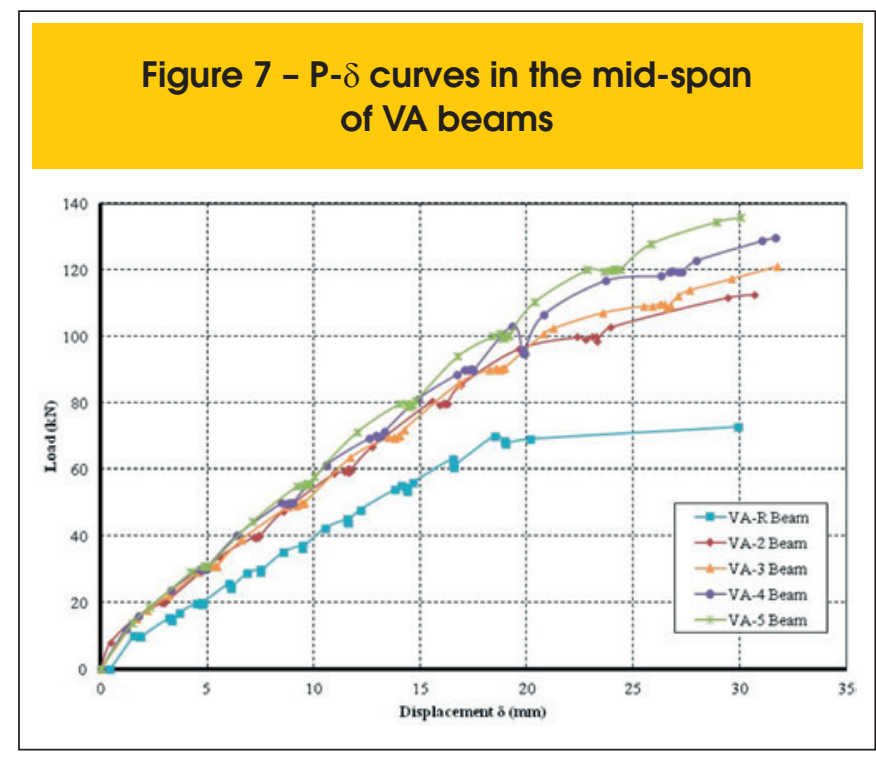

Where: $\mathrm{n}$ is the number of the CFRP layers, $E_{f c}$ is the elastic modulus of the CFRP, $t_{f c}$ is the thickness of one layer of CFRP and $x_{f c}$ is the strain of rupture of CFRP. The coefficient $k_{m}$ must multiply the CFRP failure strain in order to obtain an upper limit for its strain.

When analytical values are compared with experimental values of VA and VB beams, it is clear that the behavior exhibited by both groups was identical. For both VA and VB group, ultimate experimental loads were higher than the analytical ultimate loads to the beams with two layers of fiber and lower to beams with 3, 4 and 5 layers. The reference beams had lower analytical loads than experimental loads. However, the percentage differences between the analytical values and the experimental values is higher for the strengthened beams of VB group, possibly due to its lower reinforcement ratio, which allows a greater strain of the reinforcement, leading to beams with premature failure by pullout of concrete cover. Considering the experimental and analytical results of the ultimate loads of strengthened beams, it appears that the recommendations of 2002 release of $A C l ~ 440.2 R$ guide [10] do not prevent the occurrence of such premature failure mode.

\subsection{Vertical displacements}

Vertical load-displacement $(\mathrm{P}-\delta)$ curves in the middle of the span

\section{Figure 8 - P- $\delta$ curves in the mid-span of VB beams}

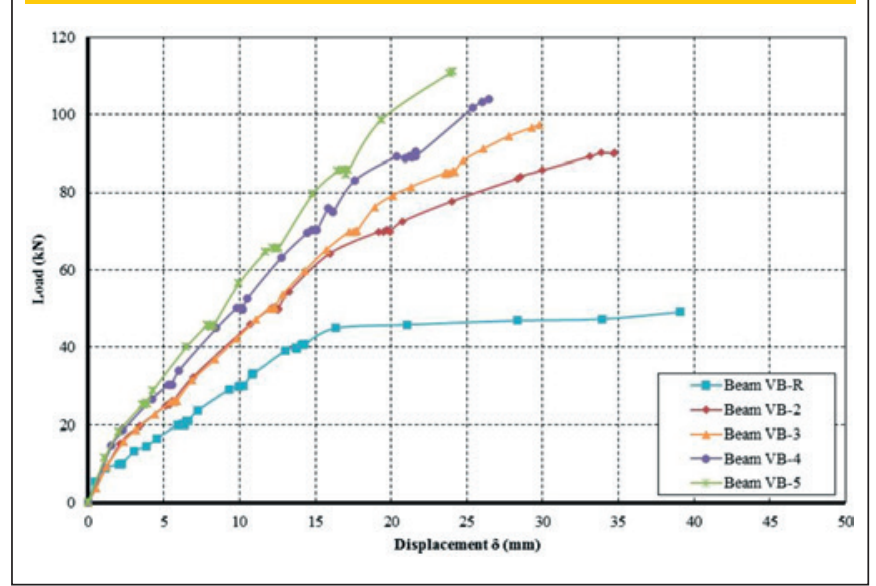

for beams of VA and VB group are shown in Figures 7 and 8, respectively, while Tables 4 and 5 shows the measured displacements of VA and VB beams, respectively, for two set values of load and for the last load. The choice of the values of $72.6 \mathrm{kN}$ and 49.1 $\mathrm{kN}$ for the VA and VA beams, respectively, was because these were the last values obtained by the data logger for reference beams of these groups, while the loads $110 \mathrm{kN}$ and $85 \mathrm{kN}$ for the VA and VB beams, respectively, were chosen because these values are close to the ultimate load of VA-2 and VB-2 beams, respectively.

Reference beams (VA-R and VB-R) presented throughout the test, for the same load level, larger displacements than the displacements of other strengthened beams of its group (Figures 7 and 8 , respectively). Specifically for strengthened beams of VA group, when compared with VA-R beam in its ultimate load $(72.6 \mathrm{kN})$, they showed a much more rigid behavior, with a reduction of displacement ranging between 55.8 and $63.2 \%$, for VA-3 and VA- 5 beams, respectively (see Table 4). Similar behavior was observed for strengthened beams of VB group, once they showed a reduction in displacements ranging from $70.8 \%$ to $78.0 \%$ when compared with VB-R displacements in its ultimate load $(49.1 \mathrm{kN}$ ) (see Table 5). Making an analysis in the displacement of VA group strengthened beams for $110 \mathrm{kN}$ and of VB group strengthened beams for 85

Table 5 - Vertical displacements of VB beams

\begin{tabular}{|c|c|c|c|c|c|}
\hline Group & Beam & $\mathrm{N}^{\circ}$ of fiber layers & $\begin{array}{l}\text { Displacement } \\
\text { for } 49,1 \mathrm{kN} \\
(\mathrm{mm})\end{array}$ & $\begin{array}{l}\text { Displacement } \\
\text { for } 85 \mathrm{kN} \\
(\mathrm{mm})\end{array}$ & $\begin{array}{l}\text { Displacement for } \\
\text { the ultimate load } \\
(\mathrm{mm})\end{array}$ \\
\hline \multirow{5}{*}{ VB } & VB-R & No reinforcement & 45.68 & - & 45.68 \\
\hline & VB-2 & 2 & 13.22 & 32.64 & 37.62 \\
\hline & VB-3 & 3 & 13.36 & 26.96 & 34.75 \\
\hline & VB-4 & 4 & 10.85 & 21.64 & 30.49 \\
\hline & VB-5 & 5 & 10.03 & 18.69 & 27.84 \\
\hline
\end{tabular}


Figure 9 - Load-strain curves of bottom reinforcement at mid-span of VA beams

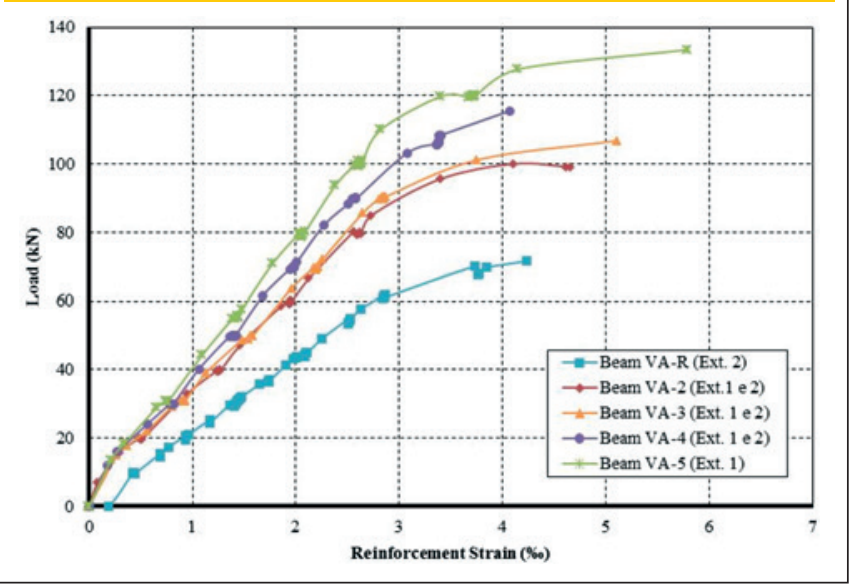

$\mathrm{kN}$, it can be seen that the greater the number of carbon fiber layers, the lower the displacements. Comparing the displacements of beams with two fibers layers of VA group (VA-2) with the values of the displacements of the strengthened beams with 3,4 and 5 layers (VA-3, VA-4 and VA-5, respectively), it is observed that these displacements were reduced by $6.1 \%, 26.1 \%$ and $31.3 \%$, respectively. Making the same analysis for the beams of group B, it follows that displacements reduction were $17.4 \%, 33.7 \%$ and $42.7 \%$, respectively. Thus, it is clear that increasing the number of carbon fiber layers increases the stiffness of the beams, reducing their displacements for the same loading level.

For the ultimate loads, strengthened beams of VA and VB groups, even increasing load capacity, had smaller displacements than the reference beams. VA-5 beam had the best performance regarding the stiffness among VA group, with a displacement $11.35 \%$ less than the VA-R beam at its ultimate load. VB- 5 beam had the best performance regarding the stiffness among VB group, with a displacement $39.05 \%$ less than VB-R.

\section{Figure 10 - Load-strain curves of bottom reinforcement at mid-span of VB beams}

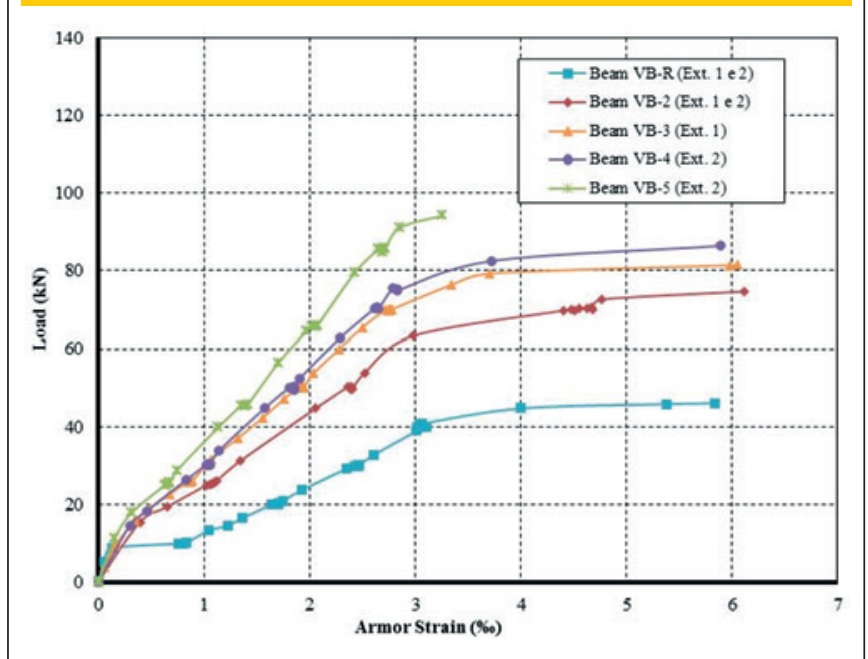

\subsection{Yielding Load and strain in the bottom reinforcement}

The load-specific deflection curves of bottom reinforcement of VA and $V B$ beams are shown in Figures 9 and 10, respectively. Tables 6 and 7 present, for VA and VB groups, respectively, the values of bottom reinforcement yielding loads, the percentage difference of the values of these loads between the strengthened beam and the reference beam, the ultimate strains in the bottom reinforcement and the percentage difference between these strains.

According Figures 9 and 10, the start of the bottom reinforcement yielding of strengthened beams occurred under loads higher than the reference beam load. The increase in these loads ranged from $42.4 \%$ to $69.3 \%$ for strengthening with 2 to 5 layers, respectively, to the VA beams (Table 6), whereas for VB beams increases ranged from $71.5 \%$ to $166.3 \%$, also for strengthening with 2 to 5 layers,

\section{Table 6 - Loads and strains in the bottom reinforcement of VA beams}

\begin{tabular}{|c|c|c|c|c|c|c|}
\hline Group & Beam & $\begin{array}{l}\mathrm{N}^{\circ} \text { of } \\
\text { fiber layers }\end{array}$ & $\stackrel{P_{y}}{(k N)}$ & $\begin{array}{c}\text { Percentage } \\
\text { difference } \\
\left(P_{y}\right)\end{array}$ & $\begin{array}{l}\text { Steel's ultimate } \\
\text { strain }(\% \circ)\end{array}$ & $\begin{array}{l}\text { Difference between ultimate } \\
\text { strains regarding to VA-R }\end{array}$ \\
\hline \multirow{5}{*}{ VA } & VA-R & $\begin{array}{c}\text { No } \\
\text { reinforcement }\end{array}$ & 56.1 & - & $4.23^{*}$ & - \\
\hline & VA-2 & 2 & 79.9 & 42.4 & $4.67^{\star}$ & $+10.4 \%$ \\
\hline & VA-3 & 3 & 82.3 & 46.7 & $5.11^{*}$ & $+20.8 \%$ \\
\hline & VA-4 & 4 & 89.9 & 60.4 & $4.06^{*}$ & $-4.0 \%$ \\
\hline & VA-5 & 5 & 94.9 & 69.3 & $5.80^{*}$ & $+37.1 \%$ \\
\hline $\begin{array}{l}\text { * - record before } \\
\text { Bottom reinforcer } \\
\text { Yielding strain of } \\
P_{y} \text { - Yielding load }\end{array}$ & $\begin{array}{l}\text { e experime } \\
\text { of VA bean } \\
\phi 12,5 \mathrm{~mm} \\
\text { reinforcem }\end{array}$ & $\begin{array}{l}\mathrm{ad} \\
2,45 \mathrm{~mm}^{2} \\
.55 \% \circ\end{array}$ & & & & \\
\hline
\end{tabular}


Table 7 - Loads and strains in the lower reinforcement of VB beams

\begin{tabular}{|c|c|c|c|c|c|c|}
\hline Group & Beam & $\begin{array}{c}\mathrm{N}^{\circ} \text { of } \\
\text { fiber layers }\end{array}$ & $\underset{(k N)}{P_{y}}$ & $\begin{array}{c}\text { Percentage } \\
\text { difference } \\
\left(P_{y}\right)\end{array}$ & $\begin{array}{l}\text { Steel's ultimate } \\
\text { strain }(\% \circ)\end{array}$ & $\begin{array}{l}\text { Difference between ultimate } \\
\text { strains regarding to VA-R }\end{array}$ \\
\hline \multirow{5}{*}{ VB } & VB-R & $\begin{array}{l}\text { No } \\
\text { reinforcement }\end{array}$ & 29.9 & - & $5.84^{*}$ & - \\
\hline & VB-2 & 2 & 51.3 & 71.5 & $6.11^{*}$ & $+4.6 \%$ \\
\hline & VB-3 & 3 & 63.7 & 113.0 & $6.05^{*}$ & $+3.6 \%$ \\
\hline & VB-4 & 4 & 67.1 & 124.3 & $5.89^{*}$ & $+0.9 \%$ \\
\hline & VB-5 & 5 & 79.7 & 166.3 & $3.25^{*}$ & $-44.4 \%$ \\
\hline $\begin{array}{l}\text { * - record before } \\
\text { Bottom reinforcer } \\
\text { Yielding strain of } \\
P_{y}-\text { Yielding load }\end{array}$ & $\begin{array}{l}\text { experime } \\
\text { o VA beam } \\
\text { \$ } 12,5 \mathrm{~mm} \\
\text { einforcem }\end{array}$ & $\begin{array}{l}\mathrm{ad} \\
1,57 \mathrm{~mm}^{2} \\
43 \% \circ\end{array}$ & & & & \\
\hline
\end{tabular}

\begin{tabular}{|c|c|c|c|c|c|c|c|}
\hline \multicolumn{8}{|c|}{ Table 8 - Ultimate strain of CFRP strengthening of VA beams } \\
\hline Group & Beam & $\begin{array}{l}\mathrm{N}^{\circ} \text { of } \\
\text { fiber layers }\end{array}$ & $\begin{array}{l}\text { Strengthening } \\
\text { strain } \\
\text { in reinforcement } \\
\text { yielding load } \\
(\% \circ)\end{array}$ & $\begin{array}{c}P_{e} \\
(k N)\end{array}$ & $\begin{array}{l}\text { Last load where } \\
\text { reinforcement } \\
\text { deformation } \\
\text { was measured } \\
\text { (kN) }\end{array}$ & $\begin{array}{l}\text { Reinforcement } \\
\text { ultimate strain } \\
(\%)\end{array}$ & $\begin{array}{l}\text { Design ultimate } \\
\text { strain according } \\
\text { to } \mathrm{ACl} 440.2 \mathrm{R} \\
(2002)(\% \circ)\end{array}$ \\
\hline \multirow{5}{*}{ VA } & VA-R & $\begin{array}{l}\text { No } \\
\text { reinforcement }\end{array}$ & - & 72.6 & - & - & - \\
\hline & VA-2 & 2 & 3.04 & 112.7 & 106.4 & 5.90 & 13.13 \\
\hline & VA-3 & 3 & 2.56 & 121.2 & 111.9 & 4.89 & 11.36 \\
\hline & VA-4 & 4 & 2.96 & 129.9 & 126.2 & 6.29 & 9.60 \\
\hline & VA-5 & 5 & 2.86 & 135.7 & 135.7 & 5.24 & 7.86 \\
\hline \multicolumn{8}{|c|}{$\begin{array}{l}\text { Bottom reinforcement area of VA beams: } A_{s}=2,45 \mathrm{~mm}^{2} \text {; Ultimate strengthening strain according to the manufacturer is equal to } 21 \% ; P_{e}- \\
\text { Ultimate experimental load }\end{array}$} \\
\hline
\end{tabular}

Table 9 - Ultimate strain of CFRP strengthening of VB beams

\begin{tabular}{|c|c|c|c|c|c|c|c|}
\hline Group & Beam & $\begin{array}{l}\mathrm{N}^{\circ} \text { of } \\
\text { fiber layers }\end{array}$ & $\begin{array}{l}\text { Strengthening } \\
\text { strain } \\
\text { in reinforcement } \\
\text { yielding load } \\
(\% \circ)\end{array}$ & $\begin{array}{c}P_{e} \\
(k N)\end{array}$ & $\begin{array}{l}\text { Last load where } \\
\text { reinforcement } \\
\text { deformation } \\
\text { was measured } \\
\text { (kN) }\end{array}$ & $\begin{array}{c}\text { Reinforcement } \\
\text { ultimate strain } \\
(\% \circ)\end{array}$ & $\begin{array}{c}\text { Design ultimate } \\
\text { strain according } \\
\text { to } \mathrm{ACl} 440.2 \mathrm{R} \\
(2002)(\% \circ)\end{array}$ \\
\hline \multirow{5}{*}{ VB } & VB-R & $\begin{array}{c}\text { No } \\
\text { reinforcement }\end{array}$ & - & 49.1 & - & - & - \\
\hline & VB-2 & 2 & 2.43 & 93.1 & 84.36 & 5.97 & 13.13 \\
\hline & VB-3 & 3 & 2.55 & 97.4 & 94.28 & 5.80 & 11.36 \\
\hline & VB-4 & 4 & 2.58 & 103.9 & 103.95 & 5.24 & 9.60 \\
\hline & VB-5 & 5 & 2.93 & 111.1 & 111.09 & 5.19 & 7.86 \\
\hline
\end{tabular}

Bottom reinforcement area of VA beams: $A_{s}=1,57 \mathrm{~mm}^{2}$; Ultimate strengthening strain according to the manufacturer is equal to $21 \%$; $P_{e}-U$ Ultimate experimental load 


\section{Figure 11 - Load-strengthening strain at mid-span of VA beams}

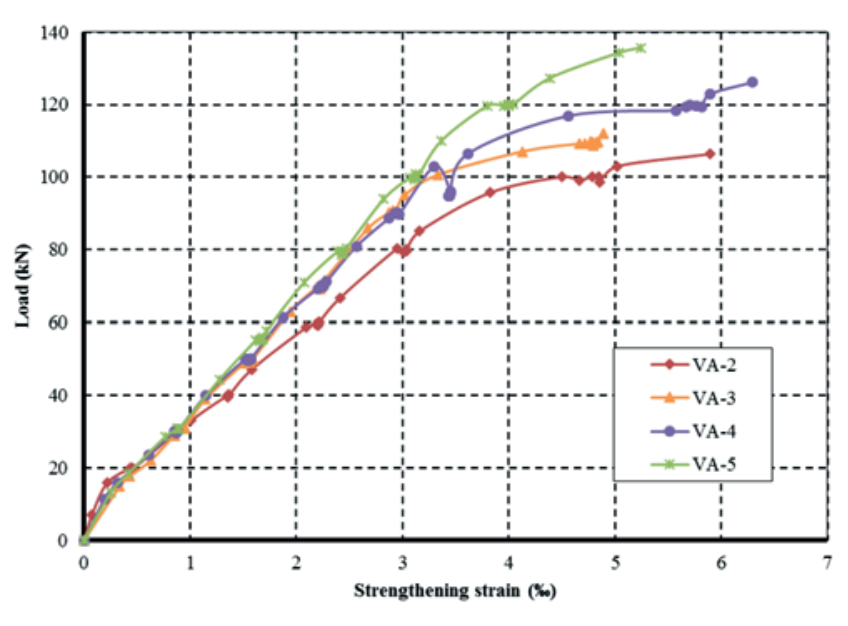

respectively (Table 7). Therefore, it is observed that the strengthening delays the beginning of the reinforcement yielding and the smaller the area of the reinforcement cross section, the lower is the reinforcement yielding load.

It is possible to see that strengthening with CFRP led, in general, to larger strains in the bottom reinforcement of VA and VB beams at the time of collapse, according to data of Tables 6 and 7, respectively. For VA beams, the ultimate strains of steel was increased with the increasing of the number of strengthening layers, except for the VA-4, reaching a maximum increased value of $37.1 \%$ for the strengthened beam with 5 fiber layers (VA-5). It was also observed higher ultimate steel strain for VB group, compared with the strains of a reference beam (VB-R), with the exception of VB-5 beam, which has presented a substantial decrease in the ultimate steel deformation. However, it is believed that this discrepancy is a result derived from any errors occurring in results acquiring.

\section{Figure 13 - Load-compressed concrete strain curves at mid-span of VA beams}

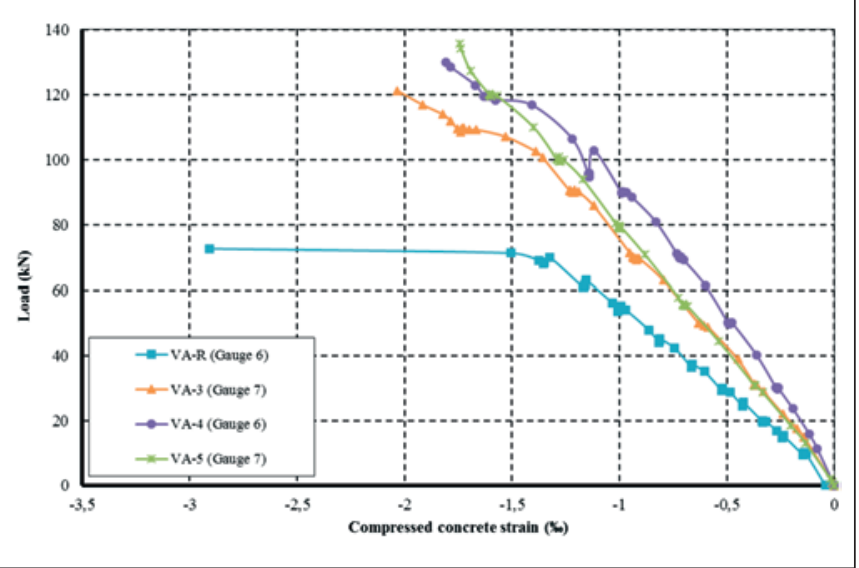

\section{Figure 12 - Load-strengthening strain at mid-span of VB beams}

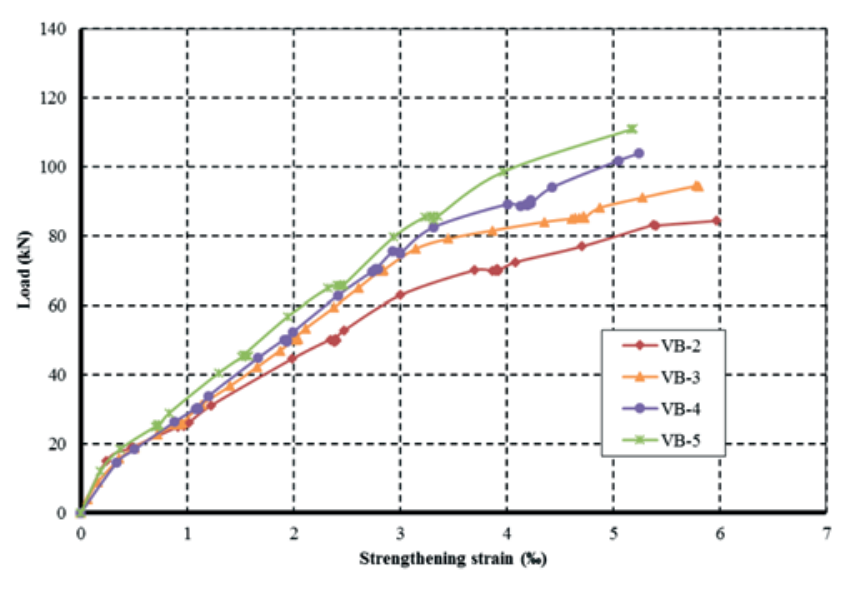

Comparing the recent increases in steel deformation of the beams of VA and VB groups, it appears that the increases in ultimate deformations obtained for VB beams were much lower than those obtained for VA beams. This can be explained because VB beams have lower reinforcement ratio than the VA beams, as well as due to the occurrence of premature failure mode.

\subsection{Strain in CFRP strengthening}

Figures 11 and 12 show load-specific strain curves of CFRP strengthening for VA and VB beams, respectively, whereas in Tables 8 and 9 are presented, for VA and VB beams, respectively, the values of strengthening strain in yielding load of beams bottom reinforcement, the ultimate experimental loads $(\mathrm{Pe})$, the last load where strengthening strain was measured and the values of these last strain measured.

As Figures 11 and 12 shows it can be noticed that the beams strengthening of VA and VB beams deform practically equal to

\section{Figure 14 - Load-compressed concrete strain curves at mid-span of VB beams}

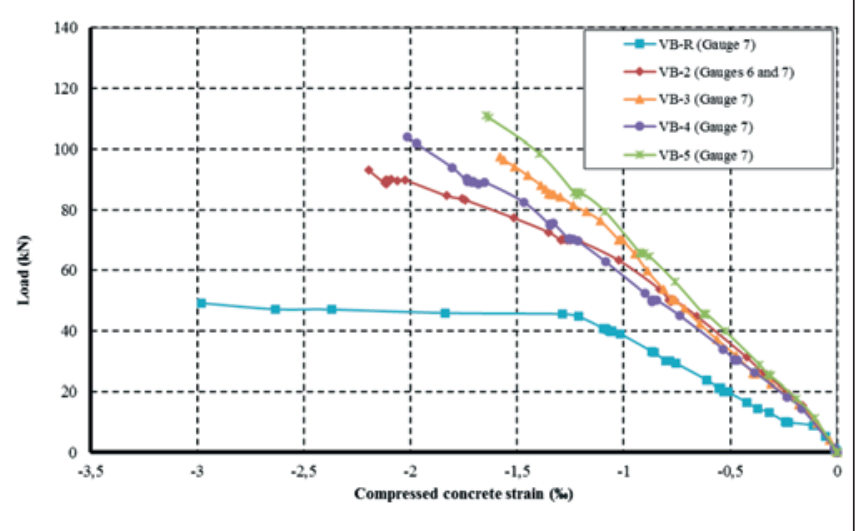




\section{Table 10 - Compressed concrete strain of VA beams}

\begin{tabular}{|c|c|c|c|c|}
\hline Group & Beam & $\begin{array}{c}\mathrm{N}^{\circ} \text { of } \\
\text { fiber layers }\end{array}$ & $\begin{array}{c}\text { Concrete strain at } 72.6 \mathrm{kN} \\
(\% \circ)\end{array}$ & $\begin{array}{l}\text { Ultimate concrete strain } \\
(\% \circ)\end{array}$ \\
\hline \multirow{5}{*}{ VA } & VA-R & No reinforcement & 2.91 & 2.91 \\
\hline & VA-2 & 2 & * & * \\
\hline & VA-3 & 3 & 0.96 & 2.03 \\
\hline & VA-4 & 4 & 0.74 & 1.81 \\
\hline & VA-5 & 5 & 0.90 & 1.74 \\
\hline $\begin{array}{l}\text { Bottom reinforce } \\
\text { * inexistent data }\end{array}$ & $\begin{array}{l}\text { A beams: } \\
\text { capture }\end{array}$ & & & \\
\hline
\end{tabular}

initial loads. However, for loads above $40 \mathrm{kN}$ it can be realized that the strengthening with less fiber layers deform more, which indicates that increasing the amount of fibers in the strengthening makes them more rigid.

According Tables 8 and 9 data, the ultimate strain measured on the VA and VB beams strengthening were very close, between $4.89 \%$ and $6.29 \%$, which are below to the ultimate strengthening strain, given by the manufacturer, which is $21 \%$. Such strains are still less to the design ultimate strain, which are obtained by multiplying the coefficient $\mathrm{km}$ (Equation 1 ) by the ultimate strain in the failure, as prescribed in 2002 release of $\mathrm{ACl} 440.2 \mathrm{R}$ guide (2002). This probably occurred due to the beams premature failure for pullout of concrete cover, as found in the works of Garden and Hollaway [24] Beber [6-7] and Garcez [25].

According to Beber [7], there is a tendency to obtain lower ultimate strain in the strengthening when the number of fiber layers is increased. This behavior is well presented in the beams of VB group. To obtain higher ultimate strain on flexural strengthening of beams, one solution would be to adopt a suitable anchor system for this strengthening, thereby preventing the premature failure mode by concrete cover pull out, as cited by Beber [7].

\subsection{Strain of compressed concrete}

Figures 14 and 15 show load-specific strain curves of compressed concrete for VA and VB beams, respectively. The strain values obtained in the strain gages to VA-2 beam have not been consistent and, therefore, were discarded. Table 10 shows the values of compressed concrete strain of VA group for the ultimate load of reference beam $(72.6 \mathrm{kN})$, as the ultimate strain of each strengthening concrete beam. Table 11 shows these same data to VB beams group, however the last load of VB-R beam is equal to $49.1 \mathrm{kN}$.

A Comparison between concrete's specific strains is an indicator of strengthened beams performance, with respect to increased rigidity, being an indicator of the strengthening applied effectiveness. It is observed that for VA strengthened beams (Table 10), the concrete ultimate strain of reference beam had a value of $43.4 \%, 60.8 \%$ and $67.2 \%$ higher than in the beams with three, four and five layers of fiber, respectively. There was an error in data acquisition which prevented the achievement of concrete strain of VA-2 beam.

For beams of VB group (Table 11), it is also observed a strengthening contribution for rigidity increasing of these beams. It is observed that concrete's ultimate strain in the reference beam of this group showed a value of $36.1 \%, 88.6 \%, 47.5 \%$ and $80.6 \%$ higher than in the beams with two, three, four and five layers of fiber, respectively. Making a comparison between the strengthened beams of VA group in $72.6 \mathrm{kN}$ (Table 10), it is observed that the beams showed similar effects up to this load regarding concrete's strain, with an exception of the four layers of strengthening beam, which presented strains below than expected. For VB beams, in the load of $49.1 \mathrm{kN}$, they showed a significant reduction in concrete's strains (between $72.5 \%$ and $77.5 \%$ ), compared to reference beam strains, and a similar behavior when compared with each other.

Analyzing carefully Figures 11, 12, 15 and 16 it can be said that

\section{Table 11 - Compressed concrete deformations of VB beams}

\begin{tabular}{|c|c|c|c|c|}
\hline Group & Beam & $\begin{array}{l}\mathrm{N}^{\circ} \text { of } \\
\text { fiber layers }\end{array}$ & $\begin{array}{c}\text { Concrete strain at } 49.1 \mathrm{kN} \\
(\% \circ)\end{array}$ & $\begin{array}{l}\text { Ultimate concrete strain } \\
\qquad(\% \circ)\end{array}$ \\
\hline \multirow{5}{*}{ VB } & VB-R & No reinforcement & 2.98 & 2.98 \\
\hline & VB-2 & 2 & 0.74 & 2.19 \\
\hline & VB-3 & 3 & 0.74 & 1.58 \\
\hline & VB-4 & 4 & 0.82 & 2.02 \\
\hline & VB-5 & 5 & 0.67 & 1.65 \\
\hline
\end{tabular}


VA-R and VB-R failures occurred as design predicted, with the bottom longitudinal reinforcement yielding and with no crushing of compressed concrete.

\section{Conclusions}

- The reinforcement with two carbon fiber layers provided an increase in final experimental load of $55.1 \%$ and $89.5 \%$ for the strengthened beams of VA and VB groups, respectively.

- For both VA and VB group of beams, it is observed that there is a small increase in the ultimate experimental load from the strengthening with 3 fiber layers.

- The reference beams from both groups presented a failure by bending while strengthened beams showed premature failure by tearing off concrete cover. Thus, the strengthening design carried out in accordance with the requirements of $\mathrm{ACl} 440.2 \mathrm{R}$ guide release 2002 [10] did not prevent the occurrence of premature failure mode.

- In both groups, the beam strengthened with 2 layers of fiber (VA-2 and VB-2) obtained analytical loads very close to experimental loads, as well as reference beam (VA-R and VB-R) obtained their ultimate experimental loads higher than the ultimate analytical loads. For beams of VA group strengthened with 3 , 4 and 5 layers of fiber it was observed an average decrease of $5.5 \%$ for experimental loads when compared to analytical loads. However, for VB beams group strengthened with 3, 4 and 5 layers of fiber, the average decrease was of around $17 \%$. This difference between the ultimate analytical and ultimate experimental loads for the strengthened beams of VA group and mainly of VB group can be explained due to the inability of design method proposed by 2002 release of $A C l 440.2 R$ guide [10] to prevent the occurrence of the premature failure mode by pullout of concrete cover of tested beams.

- The CFRP strengthening directly contributed to the rigidity increase of reinforced beams, reducing the vertical displacement of the same for a given load.

- CFRP strengthening delayed the beam's bottom longitudinal reinforcement yielding. It was observed a tendency that the smaller the strengthening cross section area, the lower the yielding reinforcement load. It was also observed that, in general, the ultimate strain of bottom reinforcement of strengthened beams of both groups were higher than the ultimate strain of bottom reinforcement of their respective reference beams.

- The ultimate strains measured in VA and VB strengthening beams were very close, between $4.89 \%$ and $6.29 \%$, that are well below of the carbon fiber ultimate strain given by the manufacturer and of the design ultimate strains. This probably occurred due to beams premature failure by pullout of concrete cover.

- It was observed that concrete ultimate strains in the upper flange of reference beams were well above to concrete ultimate strains of concrete in same location of strengthened beams.

\section{Acknowledgments}

Authors thanks to CAPES-PROPAG for the financial support regarding to the scholarship, to FUNCAP for the financial support making this research possible and to Módulo Engenharia, for its work in this research.

\section{References}

[1] MACHADO, A. P. Strengthening of reinforced concrete structures with carbon fibers - characteristics, design and application, São Paulo: Ed. PINI, 2002, 282 p. (in Portuguese).

[2] DESKOVIC, N; TRIANTAFILLOU, TC; MEIER, U. Innovative design of FRP combined with concrete - short-term behavior. Journal of Structural Engineering-ASCE. v.121, n.7, 1995; p.1069-1078.

[3] DONG, J.; WANG, Q.; GUAN, Z. Structural behavior of RC beams with external flexural and flexural-shear strengthening by FRP sheets. Composites: Part B, n.44, 2013; p.604-612.

[4] AHMED, E.; SOBUZ, H. R.; SUTAN, N. M. Flexural performance of CFRP strengthened RC beams with different degrees of strengthening schemes. International Journal of the Physical Sciences, v.6, n.9, 2011; p.2229-2238.

[5] OBAIDAT, Y. T.; HEYDEN, S.; DAHLBLOM, O.; ABU-FARSAKH, G.; ABDEL-JAWAD, Y. Retrofitting of reinforced concrete beams using composite laminates. Construction and Building Materials, n.25, 2011; p.591-597.

[6] BEBER, A. J. Performance evaluation of reinforced concrete beams strengthened with carbon fiber blades, Porto Alegre, 1999, Thesis (Dissertation) - School of Engineering, Federal University of Rio Grande do Sul, 95 p. (in Portuguese)

[7] BEBER, A. J. Structural Behavior of reinforced concrete beams reinforced with carbon fiber composites, Porto Alegre, 2003, Thesis (Doctoral) - School of Engineering, Federal University of Rio Grande do Sul, 317 p. (in Portuguese)

[8] FERRARI, V. J. Flexural strengthening of reinforced concrete beams with carbon fibers reinforced polymers (CFRP) joined to the transition substrate consisting of a high performance cementitious composite, São Carlos, 2007, Thesis (Doctoral) - School of Engineering of São Carlos, University of São Paulo, 310 p. (in Portuguese)

[9] COSTA, N. C. S. Experimental analysis of reinforced concrete beams strengthened in flexure with carbon fiber composite - anchor optimization, Belém, 2011, Thesis (Dissertation) - Faculty of Civil Engineering, Technological Institute, Federal University of Pará, 109 p. (in Portuguese)

[10] AMERICAN CONCRETE INSTITUTE. Guide for the Design and Construction of Externally Bonded FRP Systems for Strengthening Concrete Structures. ACI Committee 440.2R02, USA, 2002.

[11] SPADEA, G.; BENCARDINO, F.; SWAMY, R. N. Optimizing the performance characteristics of beams strengthened with bonded CFRP laminates. Materials and Structures, n.33, 2000; p.119-126.

[12] ESFAHANI, M. R.; KIANOUSH, M. R.; TAJARI, A. R. Flexural behavior of reinforced concrete beams strengthened by CFRP sheets. Engineering Structures, n.29, 2007; p.24282444.

[13] AL-TAMINI, A. K.; HAWILEH, R.; ABDALLA, J.; RASHEED, H. A.; F.ASCE. Effects of ratio of CFRP plate length to shear span and end anchorage on flexural behavior of SCC RC beams. Journal of Composites for Construction, n.15, 2011; p.908- 919.

[14] MOSTAFA, A.; RAZAQPUR, A. G.; CFRP anchor for pre- 
venting premature debonding of externally bonded FRP laminates from concrete. Journal of Composites for Construction, n.17, 2013; p.641-650.

[15] AMERICAN CONCRETE INSTITUTE. Guide for the Design and Construction of Externally Bonded FRP Systems for Strengthening Concrete Structures. ACl Committee 440.2R08, USA, 2008.

[16] INTERNATIONAL FEDERATION FOR STRUCTURAL CONCRETE. Externally Bonded FRP Reinforcement for Concrete Structures, FIB 2001 (Bulletin 14), Lausanne, 2001.

[17] OEHLERS, D.J., VISINTIN, P. HASKETT, M., SEBASTIAN, W.M. Flexural ductility fundamental mechanisms governing all RC members in particular FRP RC. Construction and Building Materials, v.49, 2013; p.985-997.

[18] YAU. J.; TENG. J. G. Plate end debonding in FRP-plated RC beams - I: Experiments. Engineering Structures, n.29, 2007; p.2457-2471.

[19] OEHLERS, D. J. Ductility of FRP plated flexural members. Cement \& Concrete Composites, v. 28, 2006; p.898-905

[20] SMITH, S. T.; TENG, J. G. FRP-strengthened RC beams. I: review of debonding strength models. Engineering Structures, n.24, 2002; p.385-395.

[21] TRIANTAFILLOU, T. C; PLEVRIS, N. Strengthening of RC beams with epoxy-bounded fibre-composite materials. Materials and Structures, v.25, 1992; p.201-211.

[22] SANTOS, A. R. S.; VIEIRA, M. M.; MONT'ALVERNE, A. M.; CABRAL, A. E. B.; BEZERRA, L. M.; MONTENEGRO, L. C. $S$. Determination of carbon fiber optimal area used in flexural strengthening of reinforced concrete beams. In: Brazilian Concrete Congress, 55 , Gramado, 2013, Anais (CD-ROM). (in Portuguese)

[23] MAPLE - User's Manual release 12. Waterloo Maple Inc., Waterloo, Canada, 2008.

[24] GARDEN, H. N.; HOLLAWAY, L. C. An experimental of the influence of plate end anchorage of carbon fibre composite plates used to strengthen reinforced concrete beams. Composite Structures, v.42, 1998; p.175-188.

[25] GARCEZ, M. R. Behavior of reinforced concrete beams under loading with carbon fiber mats, Santa Maria, 2002, Thesis (Dissertation) -Federal University of Santa Maria, $162 \mathrm{p}$. (in Portuguese). 